\title{
Chromate and the Environment: Removal and Utilization of Industrial Waste
}

\author{
Fernando B. Mainier, Pedro Paulo B. Leite, Marcone F. Reis and Thiago Teobaldo Silva \\ Engineering School, Federal Fluminense University(UFF), Niterói, Rio de Janeiro 24220-261, Brazil
}

\begin{abstract}
Chromate and dichromate sodium as a function of oxidizer characteristics are used in several industrial areas; for example, in surface protection of coated parts of cadmium, zinc and aluminum (chromate coated treated), corrosion inhibitors, the treatment of leather, the manufacture of pigments, etc. However, the use of such products has been questioned due to the problems of toxicity and pollution that can be caused in the environmental. The Brazilian environmental agency has established that the concentrations of chromate in water courses are less than $0.5 \mathrm{ppm}$. In order to reuse chromate $\left(\mathrm{CrO}_{4}{ }^{2-}\right)$ from industrial effluent, laboratory experiments have been proposed based on chemical reduction or electrolytic processes, in order to transform these chromate ions in a final mix of oxides (in solid form), which can then be packed and sent to the production process of sodium chromate. The results of these experiments have become useful industrially (without regard to costs) considering the environmental reuse and the life cycle of the chemical compound.
\end{abstract}

Key words: Chromate, dichromate, contamination, chemical reduction, electrolytic process.

\section{Introduction}

Industrial production processes, especially chemical ones, continue to exert strong pressure on the environment, in view of the inherent risks of their manufacturing processes in e.g.: the security industry, contamination, tailings, effluent, packaging, reuse, recycling, toxic metals and toxic waste, which often get confused or are interlinked.

Large industrial complexes such as oil and gas production, petrochemical metallurgical industries, for the most part, become polluters and end up having an impact upon the world with their waste, becoming enemies of society, sustainability and man himself. They give the impression of not taking precautions in relation to the present or the future, according to leaks, accidents and disasters that occur in various parts of the world. Some of these disasters can be associated with obsolete technologies and the direct or indirect use of recycling or recovery of packaging and toxic

Corresponding author: Fernando B. Mainier, Ph.D., professor, research fields: corrosion, corrosion protection, materials and environment. waste, among others $[1,2]$.

In order to individualize the problem of contamination of workers and environmental pollution, chromate and dichromate are highlighted, usually called hexavalent chromium compounds, because, due to their oxidizing characteristics, such products are used in various industry segments. Certain studies have argued that such products are harmful to human health, because contact can promote dermatitis, and inhalation and ingestion promote irritation and ulceration in the intestines, stomach and the risk of lung cancer [3-5].

Fig. 1 presents chromite ore $\left(\mathrm{FeO} \cdot \mathrm{Cr}_{2} \mathrm{O}_{3}\right)$ that is the main raw material for applications in different industries, such as: $76 \%$ for production of chromium and chromium alloys $[6,7] ; 13 \%$ for refractory bricks and $11 \%$ for chemicals [8-10].

Currently, chromite ore is extracted and purified in South Africa (39\%), India (16\%), Kazakhstan (15\%), and other countries as Brazil, Finland, Oman, Russia and Turkey (representing 21\%). In the 1970s to 1990s in Brazil, most of the chromite ore was intended for the production of chromate [11]. Currently, chromate is imported from South Africa. 


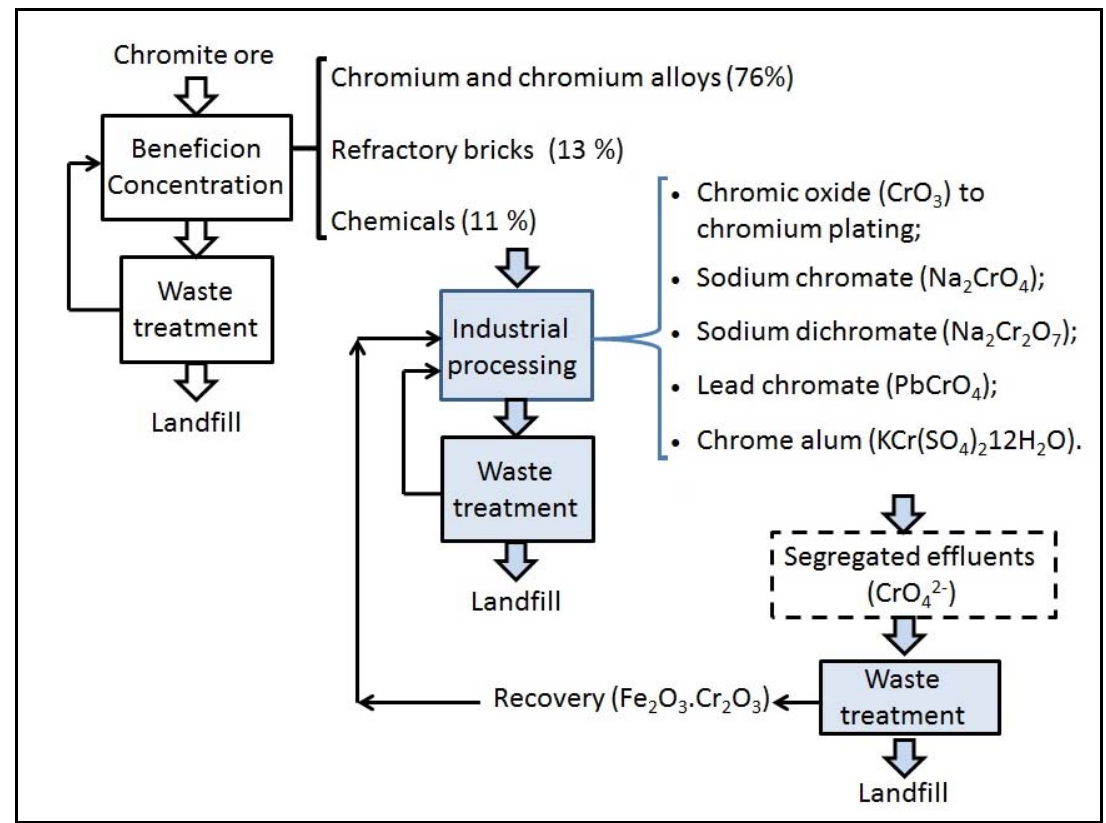

Fig. 1 Industrial routes using chromite ore.

Globally, roughly $11 \%$ of chromite ore and chrome waste are intended for the production of chemical compounds, mainly: chromic oxide $\left(\mathrm{CrO}_{3}\right)$ for chromium plating, sodium chromate $\left(\mathrm{Na}_{2} \mathrm{CrO}_{4}\right)$, sodium dichromate $\left(\mathrm{Na}_{2} \mathrm{Cr}_{2} \mathrm{O}_{7}\right)$, lead chromate $\left(\mathrm{PbCrO}_{4}\right)$, chrome alum $\left(\mathrm{KCr}\left(\mathrm{SO}_{4}\right)_{2} \cdot 12 \mathrm{H}_{2} \mathrm{O}\right)$, etc. The quality of these products depends on the origin of the raw material and industrial processing; therefore, the treatment of waste and the final disposal of this waste in landfill are both essential.

In this industrial scenario, application of the rules and regulations of Clean Technologies $[1,12]$ and the premises of LCA $[13,14]$ of materials (i.e. from the cradle to the grave from raw materials to final landfill) are important bases of environmental sustainability and human health protection from the toxicity of such products.

Clean technologies should be established in order to meet the demands for sustainability and to ensure that the environment, public health, worker safety, and the safety of the inhabitants surrounding industrial complexes are protected using methods that reduce energy, and programs that reuse or recover raw materials, in order to reduce the amount of waste generated. It is believed that the treatment or processing of waste should be carried out by those companies that generate the source of pollution (segregated treatment), because usually a great effort is accompanied by high cost of treatment to recover the final system when, in fact, it is contaminated $[1,15]$.

The reactions for obtaining sodium chromate and industrial sodium dichromate from chromite ore are presented below:

$$
\begin{gathered}
4 \mathrm{FeO} . \mathrm{Cr}_{2} \mathrm{O}_{3}+8 \mathrm{Na}_{2} \mathrm{CO}_{3}+7 \mathrm{O}_{2} \rightarrow \\
2 \mathrm{Fe}_{2} \mathrm{O}_{3}+8 \mathrm{Na}_{2} \mathrm{CrO}_{4}+8 \mathrm{CO}_{2} \\
2 \mathrm{Na}_{2} \mathrm{CrO}_{4}+\mathrm{H}_{2} \mathrm{SO}_{4} \rightarrow \\
\mathrm{Na}_{2} \mathrm{Cr}_{2} \mathrm{O}_{7}+\mathrm{Na}_{2} \mathrm{SO}_{4}+\mathrm{H}_{2} \mathrm{O}
\end{gathered}
$$

To illustrate the use of segregated waste treatment, the use of chromate as a corrosion inhibitor in a cooling system was chosen. Generally, the chromate concentration $\left(\mathrm{CrO}_{4}{ }^{2-}\right)$ can vary from $50-600 \mathrm{mg} / \mathrm{L}$ depending on the operating conditions and the water used, mainly in relation to the content of chloride $\left(\mathrm{Cl}^{-}\right)$.

To evaluate the removal and reuse of chromate, in the form of "chromite", double oxide of iron (II) and (III) chromium $\left(4 \mathrm{FeO} \cdot \mathrm{Cr}_{2} \mathrm{O}_{3}\right)$ were selected two processes. 
The first is based on chemical reduction using reducing substances such as: sodium sulfite $\left(\mathrm{Na}_{2} \mathrm{SO}_{3}\right)$, sodium bisulfite $\left(\mathrm{NaHSO}_{3}\right)$, ferrous sulfate $\left(\mathrm{FeSO}_{4}\right)$, sulfur dioxide $\left(\mathrm{SO}_{2}\right)$, whose reactions are listed below:

$$
\begin{gathered}
2 \mathrm{Na}_{2} \mathrm{CrO}_{4}+5 \mathrm{H}_{2} \mathrm{SO}_{4}+3 \mathrm{Na}_{2} \mathrm{SO}_{3} \rightarrow \\
5 \mathrm{Na}_{2} \mathrm{SO}_{4}+\mathrm{Cr}_{2}\left(\mathrm{SO}_{4}\right)_{3}+5 \mathrm{H}_{2} \mathrm{O} \\
4 \mathrm{Na}_{2} \mathrm{CrO}_{4}+7 \mathrm{H}_{2} \mathrm{SO}_{4}+6 \mathrm{NaHSO}_{3} \rightarrow \\
7 \mathrm{Na}_{2} \mathrm{SO}_{4}+2 \mathrm{Cr}_{2}\left(\mathrm{SO}_{4}\right)_{3}+10 \mathrm{H}_{2} \mathrm{O} \\
2 \mathrm{Na}_{2} \mathrm{CrO}_{4}+6 \mathrm{FeSO}_{4}+8 \mathrm{H}_{2} \mathrm{SO}_{4} \rightarrow \\
2 \mathrm{Na}_{2} \mathrm{SO}_{4}+3 \mathrm{Fe}_{2}\left(\mathrm{SO}_{4}\right)_{3}+\mathrm{Cr}_{2}\left(\mathrm{SO}_{4}\right)_{3}+8 \mathrm{H}_{2} \mathrm{O} \\
2 \mathrm{Na}_{2} \mathrm{CrO}_{4}+2 \mathrm{H}_{2} \mathrm{SO}_{4}+3 \mathrm{SO}_{2} \rightarrow \\
2 \mathrm{Na}_{2} \mathrm{SO}_{4}+\mathrm{Cr}_{2}\left(\mathrm{SO}_{4}\right)_{3}+2 \mathrm{H}_{2} \mathrm{O}
\end{gathered}
$$

Neutralization of the acid solution and the precipitation in their hydroxides and calcium sulfate $\left(\mathrm{CaSO}_{4}\right)$ can be made using calcium hydroxide or sodium hydroxide, whose reactions are presented below:

$$
\begin{gathered}
\mathrm{Cr}_{2}\left(\mathrm{SO}_{4}\right)_{3}+3 \mathrm{Ca}(\mathrm{OH})_{2} \rightarrow 2 \mathrm{Cr}(\mathrm{OH})_{3} \downarrow+3 \mathrm{CaSO}_{4} \downarrow \\
\mathrm{Na}_{2} \mathrm{SO}_{4}+\mathrm{Ca}(\mathrm{OH})_{2} \rightarrow \mathrm{CaSO}_{4}+2 \mathrm{NaOH} \\
\mathrm{Fe}_{2}\left(\mathrm{SO}_{4}\right)_{3}+3 \mathrm{Ca}(\mathrm{OH})_{2} \rightarrow 3 \mathrm{CaSO}_{4}+2 \mathrm{Fe}(\mathrm{OH})_{3} \downarrow \\
\mathrm{Cr}_{2}\left(\mathrm{SO}_{4}\right)_{3}+6 \mathrm{NaOH} \rightarrow 2 \mathrm{Cr}(\mathrm{OH})_{3} \downarrow+3 \mathrm{Na}_{2} \mathrm{SO}_{4} \\
\mathrm{Fe}_{2}\left(\mathrm{SO}_{4}\right)_{3}+6 \mathrm{NaOH} \rightarrow 3 \mathrm{Na}_{2} \mathrm{SO}_{4}+2 \mathrm{Fe}(\mathrm{OH})_{3 \downarrow}
\end{gathered}
$$

The second process is based on reduction by ferrous ions $\left(\mathrm{Fe}^{2+}\right)$ obtained by the electrolytic dissolution of carbon steel electrode by applying a continuous electric current, in acidic medium $\left(\mathrm{H}_{2} \mathrm{SO}_{4}\right)$, as shown in the following reactions:

$$
\begin{gathered}
\text { Anodic reaction: } \mathrm{Fe}-2 \mathrm{e} \rightarrow \mathrm{Fe}^{2+} \\
\text { Cathodic reaction: } 2 \mathrm{H}^{+}+2 \mathrm{e} \rightarrow \mathrm{H}_{2}
\end{gathered}
$$

Ferrous sulfate $\left(\mathrm{FeSO}_{4}\right)$ formed in solution, reacts with chromate as shown in the reaction:

$$
\begin{gathered}
2 \mathrm{Na}_{2} \mathrm{CrO}_{4}+6 \mathrm{FeSO}_{4}+8 \mathrm{H}_{2} \mathrm{SO}_{4} \rightarrow 2 \mathrm{Na}_{2} \mathrm{SO}_{4}+ \\
3 \mathrm{Fe}_{2}\left(\mathrm{SO}_{4}\right)_{3}+\mathrm{Cr}_{2}\left(\mathrm{SO}_{4}\right)_{3}+8 \mathrm{H}_{2} \mathrm{O}
\end{gathered}
$$

Later, the solution is neutralized with calcium hydroxide or sodium hydroxide as shown in the following reactions:

$$
\begin{gathered}
\mathrm{Cr}_{2}\left(\mathrm{SO}_{4}\right)_{3}+3 \mathrm{Ca}(\mathrm{OH})_{2} \rightarrow 2 \mathrm{Cr}(\mathrm{OH})_{3} \downarrow+3 \mathrm{CaSO}_{4} \downarrow \\
\mathrm{Na}_{2} \mathrm{SO}_{4}+\mathrm{Ca}(\mathrm{OH})_{2} \rightarrow \mathrm{CaSO}_{4}+2 \mathrm{NaOH} \\
\mathrm{Fe}_{2}\left(\mathrm{SO}_{4}\right)_{3}+3 \mathrm{Ca}(\mathrm{OH})_{2} \rightarrow 3 \mathrm{CaSO}_{4}+2 \mathrm{Fe}(\mathrm{OH})_{3} \downarrow \\
\mathrm{Cr}_{2}\left(\mathrm{SO}_{4}\right)_{3}+6 \mathrm{NaOH} \rightarrow 2 \mathrm{Cr}(\mathrm{OH})_{3} \downarrow+3 \mathrm{Na}_{2} \mathrm{SO}_{4} \\
\mathrm{Fe}_{2}\left(\mathrm{SO}_{4}\right)_{3}+6 \mathrm{NaOH} \rightarrow 3 \mathrm{Na}_{2} \mathrm{SO}_{4}+2 \mathrm{Fe}(\mathrm{OH})_{3} \downarrow
\end{gathered}
$$

\section{Materials and Methods}

The test of chemical reduction consisted, essentially, of a glass container $500 \mathrm{~mL}$ in volume, equipped with a magnetic stirrer, in which were placed $200 \mathrm{~mL}$ of sodium chromate solution referred to as the chromate ion $\left(\mathrm{CrO}_{4}{ }^{2-}\right)$. The chromate solutions evaluated were 100,200 and $600 \mathrm{mg} / \mathrm{L}$, were used a high purity of sodium chromate. The $\mathrm{pH}$ for each solution was adjusted in the range of 2.7-2.8 using a solution of 2 $\mathrm{M} \mathrm{H} \mathrm{H}_{2} \mathrm{SO}_{4}$. The masses of $\mathrm{Na}_{2} \mathrm{SO}_{3}, \mathrm{NaHSO}_{3}$ and $\mathrm{FeSO}_{4}$ used in the chemical reduction were determined, stoichiometrically and using, respectively, Eqs. (3-5). To guarantee the reduction of chromate ions $\left(\mathrm{CrO}_{4}{ }^{2-}\right)$ from the chromium ions $\left(\mathrm{Cr}^{3+}\right)$, the calculated masses were multiplied by 1.1. Then, aiming at the removal of precipitates, were added to the resulting solution sodium hydroxide or calcium hydroxide based on earlier Eqs. (7, 9-11), with an increase of 1.1 of the mass calculated. Finally, the solution is filtered through a filter press to remove the precipitate formed and, in the resulting solution, the chromate content was determined that had not been removed.

In the experiments based on the reduction by ferrous ions $\left(\mathrm{Fe}^{2+}\right)$, an electrolytic cell (Fig. 2) consisting of an acrylic container with a maximum capacity of $500 \mathrm{~mL}$ was used, containing the anode and the cathode of carbon steel connected to a power supply of adjustable direct current (current rectifier) with a maximum voltage of $30 \mathrm{~V}$.

The current ranged from 0.2-0.6 $\mathrm{A}$ and the time ranged from 10-30 minutes, were placed in the cell $200 \mathrm{~mL}$ of high purity sodium chromate solution (100, $200,600 \mathrm{mg} / \mathrm{L})$, referred to as the chromate $\left(\mathrm{CrO}_{4}{ }^{2-}\right)$ ion. The $\mathrm{pH}$ for each solution was adjusted in the range of 2.7-2.8 using a solution of $2 \mathrm{M} \mathrm{H}_{2} \mathrm{SO}_{4}$.

Some of the operational conditions, such as the time and current/voltage for this experiment, were based on Faraday's law,

$$
\mathrm{m}=\mathrm{Zit}
$$

where, 


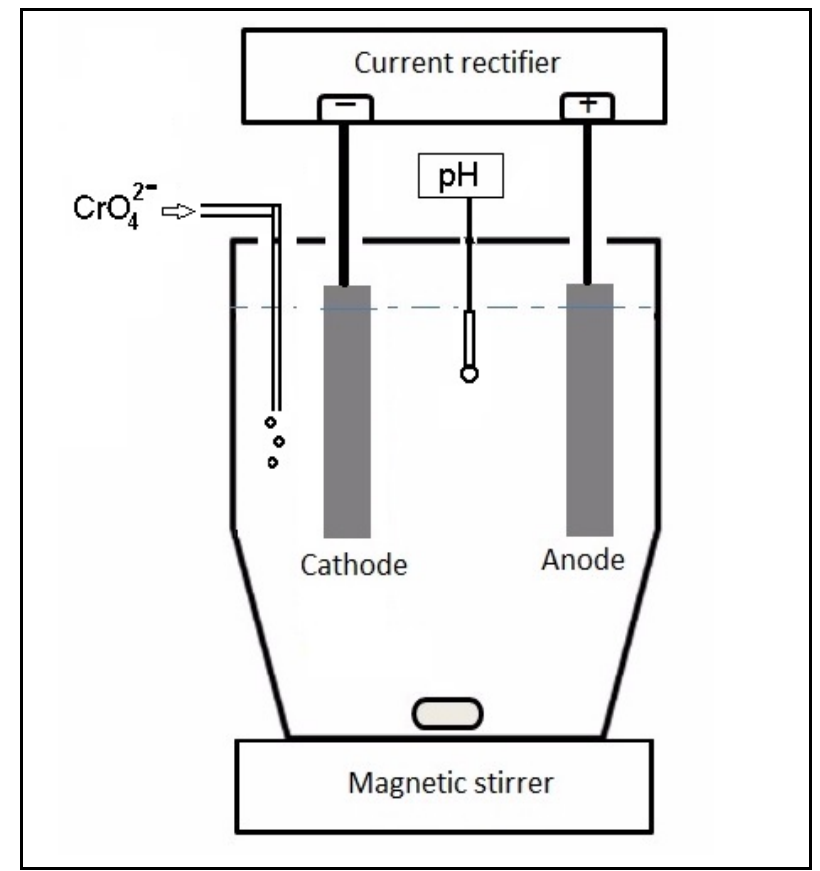

Fig. 2 Diagram of electrolytic cell.

$\mathrm{m}=$ mass, $\mathrm{g}$;

$\mathrm{Z}=$ electrochemical equivalent $(\mathrm{g} / \mathrm{C})$;

$\mathrm{i}=$ current, $\mathrm{A}$;

$\mathrm{t}=$ time, $\mathrm{h}$.

Eq. (20) requires that the amount of substance formed $\left(\mathrm{Fe}^{2+}\right)$ be directly proportional to the current passed through the electrolytic solution.

At the end of the reaction, the solution is transferred to a beaker of $500 \mathrm{~mL}$ where calcium hydroxide or sodium hydroxide are added to neutralize and precipitate the ions $\mathrm{Cr}^{3+}$ and $\mathrm{Fe}^{3+}$ ions formed. The mass of $\mathrm{Ca}(\mathrm{OH})_{2}$ or $\mathrm{NaOH}$ is calculated on the basis of the Eqs. (7, 9-11) with an increase of 1.1 of the theoretical mass calculated. Finally, the solution is filtered through a filter press to remove the precipitate formed and, in the resulting solution, the chromate content was determined that had not been removed.

After executing the removal experiments, the residual concentrations of total chromium ions $\left(\mathrm{Cr}^{3+}\right)$ in each sample were checked using a voltammetric analyzer (VA 767 Metrohm Computrace). This equipment works with three electrodes combined: the working electrode (mercury multimode), reference electrode (Ag/AgCl-KCl 3.0 mole/L) and an auxiliary platinum electrode. The total chromium ions $\left(\mathrm{Cr}^{3+}\right)$ were transformed in chromate ions $\left(\mathrm{CrO}_{4}{ }^{2-}\right)$.

The removal efficiencies were then calculated using Eq. (21).

$$
E_{\text {effic }}=\left(C_{\text {init }}-C_{\text {final }} / C_{\text {init }}\right) 100
$$

where,

$\mathrm{E}_{\text {effic }}=$ efficiency of removal (\%);

$\mathrm{C}_{\text {init }}=$ initial concentration of $\mathrm{CrO}_{4}{ }^{2-}, \mathrm{mg} / \mathrm{L}$;

$\mathrm{C}_{\text {final }}=$ final concentration of $\mathrm{CrO}_{4}{ }^{2-}(\mathrm{mg} / \mathrm{L})$ after the removal process.

\section{Results and Discussion}

The results of the chromate removal efficiency using the process of chemical reduction and electrolytic reduction are presented below in Tables 1 and 2 .

The results presented show the removal processes of chromate ions from aqueous solutions, although laboratory levels are interesting and show that it is possible to reuse the product removed. Such results refer to tests conducted with high-purity chemicals. The following points can be noted.

- A mixture of sulfite and sodium bisulfite with impurities from recovery of industrial processes proved to be less effective in laboratory tests at about $20-25 \%$; however, the price of this product was of $80 \%$ of the value of the mixture compared to high-purity products;

Table 1 Chromate removal efficiency for chemical reduction.

\begin{tabular}{llll}
\hline \multirow{2}{*}{$\begin{array}{l}\text { Chromate }\left(\mathrm{CrO}_{4}{ }^{2-}\right) \\
\text { concentration }(\mathrm{mg} / \mathrm{L})\end{array}$} & \multicolumn{3}{c}{ Removal efficiencies (\%) } \\
\cline { 2 - 4 } & $\mathrm{Na}_{2} \mathrm{SO}_{3}$ & $\mathrm{NaHSO}_{3}$ & $\mathrm{FeSO}_{4}$ \\
\hline 100 & 93.82 & 92.85 & 92.10 \\
200 & 94.25 & 93.12 & 93.83 \\
600 & 95.80 & 94.15 & 93.14 \\
\hline
\end{tabular}

Table 2 Chromate removal efficiency by electrolytic reduction.

\begin{tabular}{ll}
\hline $\begin{array}{l}\text { Chromate }\left(\mathrm{CrO}_{4}{ }^{2-}\right) \\
\text { concentration }(\mathrm{mg} / \mathrm{L})\end{array}$ & $\begin{array}{l}\text { Removal } \\
\text { efficiencies }(\%)\end{array}$ \\
\hline 100 & 92.23 \\
200 & 92.73 \\
600 & 93.68 \\
\hline
\end{tabular}


- The use of electrolytic reduction with steel anodes (scraps) becomes a cleaner option, however, with higher cost due to the high prices of DC sources;

- Neutralization with sodium hydroxide is more efficient because it reduces the waste mass compared to calcium hydroxide that produces $\mathrm{CaSO}_{4}$;

- The residue containing $\mathrm{CaSO}_{4}$ can be undesirable in chromate recovery;

- The addition of aluminum sulfate $\left[\mathrm{Al}_{2}\left(\mathrm{SO}_{4}\right)_{3}\right]$, the polyaluminum chloride (PAC) or polyelectrolyte (auxiliary flocculating) favors chromium hydroxide precipitation during sodium hydroxide neutralization.

Various studies have shown that the treatment of end-of-line generally increases the environmental impact, because of the amount of energy used and the major areas used in these projects. However, projects that use segregated systems have reduced costs and better recovery of the contaminant. Recovery of chromium $\left(\mathrm{Cr}^{+6}, \mathrm{Cr}^{+3}\right)$ in industrial effluents has presented the advantages based on the philosophies of LCA aimed at environmental protection and indirectly reducing mining activities using waste-containing chromium [16-18].

\section{Conclusions}

Based on the literature and laboratory tests, the following conclusions are made:

- It is important to consider the toxic properties of hexavalent chromium compounds used in several industrial segments and propose the gradual deactivation of these compounds, replacing them with other non-toxic substances or processes based on chrome recovery based on clean technologies and philosophies of LCA;

- The percentage of chromate removal due to the addition of $\mathrm{Na}_{2} \mathrm{SO}_{3}, \mathrm{NaHSO}_{3}$ and $\mathrm{FeSO}_{4}$ in the standardized solutions of 100, 200 and $600 \mathrm{mg} / \mathrm{L}$ was higher than $92 \%$. Electrolytic treatment using anodes of carbon steel with a maximum voltage of $30 \mathrm{~V}$, current ranging from 0.2-0.6 $\mathrm{A}$ and time from 1030 minutes, also showed the same results;

- The addition of aluminum sulfate or polyaluminum chloride (PAC) favors chromium hydroxide precipitation during sodium hydroxide neutralization.

\section{References}

[1] Mainier, F. B., Mainier, R. J., and Cardoso, V. L. S. 2013. "Clean Technology and Industrial Safe: A Right of Society." International Journal of Multidisciplinary Sciences and Engineering 4 (5): 1-6.

[2] Mainier, F. B., Pontual, L., Oliveira, R. T. Q., and Santos, I. O. 2015. "Contamination Precautions for Chemicals Which May Be Used in Drinking Water Treatment." Journal of Materials Science and Chemical Engineering 3: 63-71.

[3] Costa, M., and Klein, C. B. 2006. "Toxicity and Carcinogenicity of Chromium Compounds in Humans." Critical Reviews in Toxicology 36 (2): 155-63.

[4] Wise, S. S., Holmes, A. L., and Wise, J. P. 2006. "Particulate and Soluble Hexavalent Chromium Are Cytotoxic and Genotoxic to Human Lung Epithelial Cells." Mutation Research/Genetic Toxicology and Environmental Mutagenesis 610 (1): 2-7.

[5] Holmes, A. L., Wise, S. S., and Wise, J. P. 2008. "Carcinogenicity of Hexavalent Chromium." The Indian Journal of Medical Research 128 (4): 353-72.

[6] Lai, G. Y. 2007. High-temperature Corrosion and Materials Applications. ASM International, Ohio, USA.

[7] Nriagu, J. O. 1988. Production and Uses of Chromium. Chromium in the Natural and Human Environments. Wiley, New York.

[8] Buxbaum, G. 2008. Industrial Inorganic Pigments. John Wiley \& Sons, New York.

[9] Sundar, V. J., Rao, J. R., and Muralidharan, C. 2002. "Cleaner Chrome Tanning-emerging Options." Journal of Cleaner Production 10 (1): 69-74.

[10] Jacobs, J. A., and Testa, S. M. 2005. "Overview of Chromium (VI) in the Environment: Background and History." Chromium (VI) handbook, CRC Press, 1-21.

[11] Murthy, Y. R., Tripathy, S. K., and Kumar, C. R. 2011. "Chrome Ore Beneficiation Challenges \& Opportunities-A Review." Minerals Engineering 24 (5): 375-80.

[12] Van Berkel, R. 2007. "Eco-efficiency in Primary Metals Production: Context, Perspectives and Methods." Resources, Conservation and Recycling 51 (3): 511-40.

[13] Khasreen, M. M., Banfill, P. F., and Menzies, G. F. 2009. "Life-Cycle Assessment and the Environmental Impact of Buildings: A Review." Sustainability 1 (3): 674-701. 
[14] Azapagic, A., 1999. "Life Cycle Assessment and Its Application to Process Selection, Design and Optimization." Chemical Engineering Journal 73: 1-21.

[15] Frischknecht, R., Jungbluth, N., Althaus, H. J., Bauer, C., Doka, G., Dones, R., Hischier, R., Hellweg, S., et al. 2007. Implementation of Life Cycle Impact Assessment Methods. Ecoinvent report, 3, Dübendorf.

[16] Macchi, G., Pagano, M., Pettine, M., Santori, M., and Tiravanti, G. 1991. "A Bench Study on Chromium
Recovery from Tannery Sludge.” Water Research 25 (8): 1019-26.

[17] Fabbricino, M., Naviglio, B., Tortora, G., and Antonio, L. 2013. "An Environmental Friendly Cycle for Cr(III) Removal and Recovery from Tannery Wastewater." Journal of Environmental Management 117: 1-6.

[18] Kowalski, Z., and Wzorek, Z. 2002. "Utilisation of Chromic Waste in the Sodium Chromate (VI) Production Process." Journal of Loss Prevention in the Process Industries 15 (3): 169-78. 